\title{
地中熱交換器内の熱媒体温度挙動を用いた 地層別有効熱伝導率の推定
}

\author{
阪田 義隆 1 ・葛 隆生 2 ・翟 $\quad$ 健 3 ・長野 克則4 \\ 1正会員 北海道大学大学院特任助教 工学研究院（ $\overline{0} 060-8628$ 札幌市北区北13西8） \\ E-mail: y-sakata@eng.hokudai.ac.jp \\ 2非会員 北海道大学大学院准教授 工学研究院（干060-8628 札幌市北区北13西8） \\ E-mail: katsura@eng.hokudai.ac.jp \\ 3非会員 新菱冷熱工業株式会社・元 北海道大学大学院博士後期課程（ $\bar{T} 160-8510$ 東京都新宿区四谷2-4） \\ E-mail: zhaijian0117@gmail.com \\ 4非会員 北海道大学大学院教授 工学研究院（ \\ E-mail: nagano@eng.hokudai.ac.jp
}

\begin{abstract}
本研究では, 地中熱交換器の熱応答試験において，2本の光ファイバー温度計をUチューブに挿入し，熱 媒体の往き還りの温度挙動を測定することで，地層別の有効熱伝導率を推定する手法を提案する. 従来の 線熱源理論に基づく解析法を適用し，計算に必要となる温度の時間变化は光ファイバー温度計の多点測定 データから層内で平均し，熱交換量は温度の深度勾配の往き還りの和から求める。 その際，測定データは 系統誤差の校正と偶然誤差を最小とする平均処理で補正する。北海道旭川市での解析事例では, 有効熱伝 導率は層厚 $20 \mathrm{~m}$ 以上で安定した推定值が得られ，最上位の砂礫層の值は他 2 層より約 1.5 倍高い結果となっ た. また3層の層厚重み付け平均は従来法の結果と整合し, スムージング, ブートストラップ法, 回復時 法とデータ処理を変えても結果に差はなかった.
\end{abstract}

Key Words : effective thermal conductivity, thermal response test, fiber-optic distributed temperature sensor, line heat source theory, multi-layered formation

\section{1. はじめに}

\section{(1) 研究の背景}

地球温暖化対策としての $\mathrm{CO}_{2}$ 排出抑制と東日本大震災 以降のエネルギー需給の急変により，一層の省エネルギ 一化と再生可能エネルギ一の利用拡大が求められている. 最新のエネルギー基本計画1によれば，2030年度には 2013年度に比べ省エネルギーと再生可能エネルギーの利 用により約4割の総発電電力量の削減を目標としている また再生可能エネルギーの利用は現在, 太陽光発電など 一偏りが見られ，多様なエネルギーへの分散による安定 利用と導入コスト削減が課題となっている.

再生可能エネルギーの内，地中熱は深度 $200 \mathrm{~m}$ より浅 い地盤に賦存する温度が数 $10^{\circ} \mathrm{C}$ 以下の低温の熱エネルギ 一として定義される21. 地中熱の起源は，太陽光が地表 面を通じ地中へ伝熱したエネルギーの蓄積であり，深部 熱流体を起源とする地熱エネルギーと区別される，地温 は一般に気温に比べ安定するため，特に夏，冬での温度
差を利用し，建物の空調設備の熱源として利用する。こ のための地中熱交換器（ボアホール），ヒートポンプ, 二次側設備など一体を地中熱利用ヒートポンプシステム (Ground Source Heat Pump System: GSHPs) と呼ぶ.

地中熱は，他エネルギーに比べ，どこでもだれでもい つでも利用できるユビキタス性が特徵であるほか，地中 熱ヒートポンプは特に暖房運転時には高いエネルギー消 費効率（COP）を実現し，また冷房運転時には大気に排 熱せず環境負荷が小さいメリットがあり，特に欧米を中 心に普及が進んでいる3帟ど。一方，わが国では諸外国に 比べ普及が遅れており, その要因として, 冷房用として 高効率の空気熱源ヒートポンプ（エアコン）が既に普及 していることに加え, 地中熱交換器設置時の初期コスト が挙げられる.わが国の場合，土地の制約や地下水揚水 規制などから，鉛直方向に地中熱交換器を埋設し，水や 不凍液などの熱媒体を循環させ間接的に採放熱する，垂 直埋設方式のクローズド型が主流である，その設置深度 は100 m前後が多く，大規模施設になると10１00 本単位， 
掘削の総延長は数〜数 $10 \mathrm{~km}$ に達することもある. この ため，更なるGSHPsの普及促進のためには，地中熱交換 器の設置コストの軽減や適正化が課題となっている.

\section{（2）地盤の有効熱伝導率と熱応答試験}

地中熱交換器の熱交換量を左右する地盤特性が有効熱 伝導率である. 有効熱伝導率は, 地層を構成する土粒子 などの個体部分と間隙率と飽和度により決まり, 粘土や 火山灰のように間隙が大きい材料の場合, 有効熱伝導率 は $1.0 \mathrm{~W} /(\mathrm{m} \cdot \mathrm{K})$ 程度と低く, 緻密な花崗岩の場合 3.0 $\mathrm{W} /(\mathrm{m} \cdot \mathrm{K})$ 程度の高い值となる ${ }^{4}$. 比較的地質が単調な欧米 に対し，わが国の場合，地質はより複雑であり，特に地 中熱利用が期待される都市部の堆積平野には，異なる有 効熱伝導率の地層が互層を形成し，地中熱交換器の性能 は地域や箇所で異なることが多い，これら地層の内，早 い地下水流れがある帯水層が分布する場合，熱の移流効 果により見かけ上，有効熱伝導率が高くなる．わが国の 代表的なGSHPs設計性能予測ツールであるGround Club を用いた感度解析の結果では, 地下水流速が300 m/yを 超えると，有効熱伝導率は見かけ上，数〜10倍以上にな る5。特に地下水流動系の流出域（湧水箇所）, 高い動 水勾配と透水性が期待できる地域（扇状地など）あるい は, 地下水との交流が活発な河川周辺などで, 移流効果 による地中熱交換器の性能向上が期待できる.

熱応答試験（サーマルレスポンステスト）は, GSHPs 設計時あるいは設計後の性能確認時に, 実際の地中熱交 換器を用いて, 地盤の有効熱伝導率を推定する試験であ る. 80 年代より欧米で開発が進みのわ，我が国でも紹介さ れてきた8).99. 現在は，そのガイドラインが環境省や国 交省にて策定され ${ }^{10,11)}$ ，環境省や東京都の関連補助金の 交付を受ける際も実施が義務付けられている.

熱応答試験では，地中熱交換器の採熱管（Uチュー ブ）内で熱媒体を一定条件で加熱し，その循環温度を地 表部で測定する. 熱媒体の往き還りの温度差から, 熱交 換器全体での地盤との熱交換量を求め, Kelvinの線熱源 理論を地中熱交換器の温度挙動に適用した解析的手法 ${ }^{22}$ により, 有效熱伝導率を推定する. 得られる有効熱伝導 率は, 地中熱交換器全体の平均的な值として解勫される. 熱媒体を加熱・循環して行うため，「加熱時法」あるい は「循環時法」とも呼ばれるが，ここでは提案する手法 と比較するため, 「従来法」と称することとする.

\section{（3）熱応答試験における地層別有効熱伝導率の推定}

地質が複杂隹なわが国の場合, 地中熱交換器を埋設する 深度 $100 \mathrm{~m}$ 程度まで単一の地層で構成されることは稀で あり, 地盤の有効熱伝導率は深度毎に変化すると想定さ れる. 特に地下水が豊富な地域では, 高透水性の地層に 地下水流れが卓越する可能性もある。 こうした有効熱伝
導率の地層別の分布を把握できれば，值の高い地層に着 目した地中熱交換器の配置により, 効率的な地中熱利用 が可能になると期待される.

熱応答試験により，地層別の有効熱伝導率を把握する 最も直接的な方法は, 異なる深度に地中熱交換器を設置 し，それぞれで熱応答験を行うことである13). しかしな がら, 試験用の熱交換器の設置費用を考えると現実的で はない. このため, 単一の地中交換器を用いて, 従来の 熱忘答試験の延長として, 地層毎あるいは一定深度毎の 有効熱伝導率を推定する手法が求められる.

有効熱伝導率の分布は試験中の地下温度の挙動や分布 に反映される. この地下温度測定に際し, 熱応答試験に おいては, 光ファイバー温度計の利用が着目される. 光 ファイバー温度計では, 光ファイバーにパルス光を入射 し，ファイバーに沿った各点で生じる後方ラマン散乱効 果の温度依存を利用して温度を測定する ${ }^{14}$. 数 $\mathrm{km}$ 先まで 光信号の損失が少ないため, 深度 $100 \mathrm{~m}$ 程度の地中熱交 換器内でも多点測定が可能である. また, 光ファイバー の径も小さく, 内径数 $10 \mathrm{~mm}$ 小チューブに挿入しても 熱媒体の循環を妨げることなく, 温度測定が可能である.

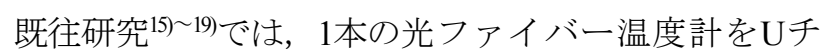
ューブの往き還りのいずれかに挿入もしくはUチュ ーブ外に埋設し, 測定温度の挙動が理論解や数值モ デルと整合するよう, 深度毎の有効熱伝導率を同定 する, 逆解析的アプローチが採用されてきた。これ ら研究成果により従来の熱応答試験では得られなか った地中熱交換器周辺の深度別の有効熱伝導率が推 定可能となったが，特殊な数值計算技術や収束判定が必 要であり, 実務での活用は未だ少ないのが現状である.

\section{(4) 本研究の目的及び内容}

本研究では, 2本の光ファイバー温度計を用いて, 垂 直埋設方式のクローズド型地中熱交換器周辺の地層別有 効熱伝導率を推定する熱応答試験法を提案する. 先行研 究が1本の光ファイバー温度計を用いて測定した温度挙 動から深度毎の有効熱伝導率を逆解析寸るのに対し, 本 研究では, 2本の光ファイバー温度計をUチューブに挿 入し, 熱媒体の往き還りの温度挙動を測定することで, 地層毎の熱交換量を求め, 線熱源理論に基づく解析法か ら地層別有効熱伝導率を推定する. 無限線熱源近似が成 り立つためには，一定以上の層厚の地層が対象となるが, 地中熱交換器の埋設深度が100 $\mathrm{m}$ 程度, 掘削単位が $10 \mathrm{~m}$ 単位であることを考慮すると, 地層別の有効熱伝導率の 推定でも実務上十分であり, 従来の熱応答試験の試験・ 解析法の延長として, より積極的な利用が期待できる.

本論文では先ず，2本の光ファイバー温度計を用いた 熱応答試験の概要を示す. 次いで線熱源理論に基づく解 析的手法を解説し，これを複層地盤へ適用手法を提案す 
る. また光ファイバー温度計の測定誤差について考察し, 室内試験にて系統誤差の校正と偶然誤差を最小化する平 均処理を行う。最後に, 北海道旭川市での解析事例を紹 介し, 有効熱伝導率の推定值の層厚に対寸る安定性や, 従来法での解析結果やデータ処理を変えた場合における 解析結果の比較を通じ, 本手法の有效性を示す.

\section{2. 試験 · 解析方法}

\section{(1) 光ファイバ一温度計を用いた熱応答試験}

2本の光ファイバー温度計を用いた熱応答試験の概要 を図-1に示す，図-1では，地中熱交換器の下底までN層 の複層地盤を想定し， $i$ 層 $(i=1 \sim N)$ の有效熱伝導率を $\lambda_{\mathrm{s}}$, 層厚 $L i$, 層下底の地表からの深度を $Z_{b i}$ としている. 各地 層の深度分布は，地中熱交換器の施工記録（柱状図）に より既知であるとする．また実際の地層構造は水平とは 限らないが, 熱䒚答試験で行う加熱時間では周辺温度の 影響は限定的なため, 近似的に水平多層構造と見なす。

通常の熱応答試験の試験機器は, 地中熱交換器, 熱媒 体の加熱ヒーターと循環ポンプ，Uチューブの地表部で 往き還り温度を測定する白金測温抵抗体（Pt100温度 計）とデータ集積器（ロガー）で構成される．これらに 加え, 新たに2本の光ファイバー温度計をUチューブの 往き還りにそれぞれ挿入し，試験中の熱媒体の往き還り の温度挙動を測定する. 図-1では, 熱応答試験での加熱 経過時間 $\tau$, 地表からの深度飞に対し, 往き・還りの熱 媒体の温度がそれぞれ $t_{\mathrm{fj}}(\mathrm{z}, \tau), j=1,2$ で示されている. 添 字のfは熱媒体を， $j=1,2$ は往き，還りを表す．光ファイ バー温度計は様々なメーカーで販売されているが，本研 究では, エーピー・センシング社の測定器(DTS N4385A 型)を光信号の受発信機とするエヌケーシステム社の光 ファイバー温度情報システム（NK-OPTIS）を用いた。

熱応答試験中, 光ファイバー温度計による熱媒体の温 度測定を連続的に行う。本研究で用いる光ファイバー温

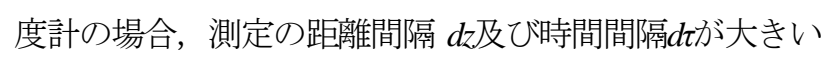
ほど 1回あたりの測定值は安定するが，本研究では， $d z$,

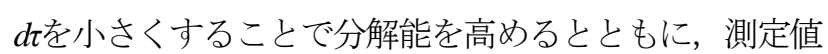
を各層内で平均化することで精度を高めることとし, 深

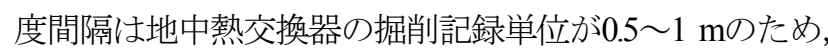
$d z=0.5 \mathrm{~m}$, 時間間隔は加熱開始や停止直後に分単位で温 度が変化するため,$d \tau=1 \mathrm{~min}$ とそれぞれ設定した。

\section{（2）線熱源理論に基づく解析的手法}

\section{a) 地中熱交換器全体での有効熱伝導率の推定 (従来法)}

先ず，従来の熱応答試験における線熱源理論に基づく 解析的手法を解説する．等方，均質で初期温度一定の無 限遠領域にて, 地中熱交換器の中心軸に, 試験時の熱交

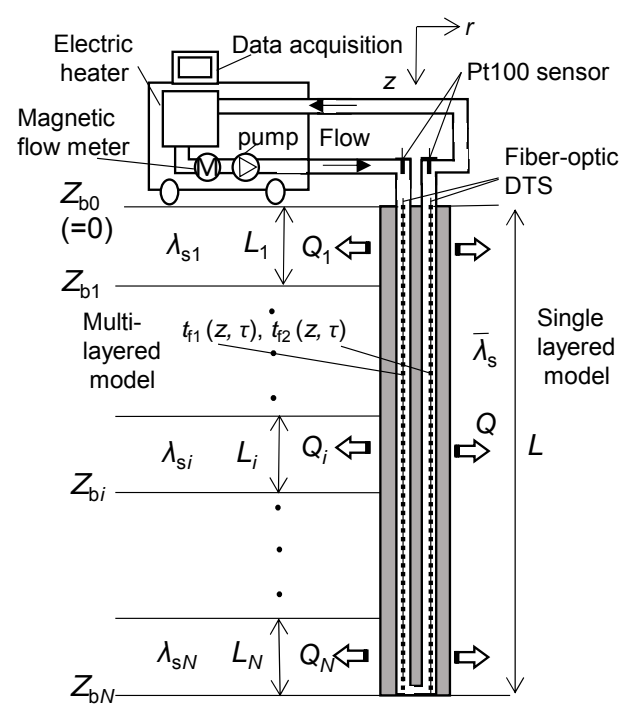

図-1 従来の熱応答試験への光ファイバー温度計の適用 概念図

換量 (加熱量) を深度当り均等に与えた無限延長の線熱 源を考える. この場合, 地中熱交換器の周辺温度 $t\left({ }^{\circ} \mathrm{C}\right)$ は，加熱経過時間 $\tau(\mathrm{hr})$ の対数に対し比例的に上昇する。

$$
t(\tau)=k \ln \tau+l
$$

ここで, $k$ は対数時間サイクルにおける温度上昇の勾配 (K/n cycle), l は時間に依存しない定数項 $\left({ }^{\circ} \mathrm{C}\right)$ である. $t(\tau)$ は，Pt100温度計で測定する地表での往き還り熱媒体温 度 $t_{\mathrm{pt}}\left(\fallingdotseq \mathrm{t}_{\mathrm{fl}}(0, \tau)\right), \mathrm{t}_{\mathrm{p} 2}\left(\fallingdotseq \mathrm{t}_{\mathrm{p}}(0, \tau)\right)$ の平均とすることが多い.

$k$ は, 地中熱交換器内外の温度差が無視できる $\tau=12 \sim 60$ $\mathrm{hr}$ （最低 $48 \mathrm{hr}$ ）の加熱時間に対し，熱媒体温度を片対数 プロットし目視で引いた直線の対数 1 目盛での変化量と して，あるいは式(1)を仮定した最小二乗法から求める8). 地中熱交換器の地盤との熱交換量 $Q(\mathrm{~W})$ は, 熱媒体の 往き還りの地表での温度差 $\Delta t(\mathrm{~K})$ から下式で計算する.

$$
Q=c_{\mathrm{f}} \rho_{\mathrm{f}} v_{\mathrm{f}} \Delta t=c_{\mathrm{f}} \rho_{\mathrm{f}} v_{\mathrm{f}}\left(t_{\mathrm{pt1}}-t_{\mathrm{p} 22}\right)
$$

ここで，Cfは熱媒体の比熱 $(\mathrm{J} /(\mathrm{kg} \cdot \mathrm{K})) ， \rho_{\mathrm{f}}$ は密度 $\left(\mathrm{kg} / \mathrm{m}^{3}\right) ， v_{\mathrm{f}}$ は循環流量 $\left(\mathrm{m}^{3} / \mathrm{s}\right)$ である. 試験中の加熱ヒーターの出力 を一定とすると, $k$ を推定する一定時間経過した後は, Qの值もほぼ安定する.これらの值を用いて, 地中熱交 換器を設置した深度全体での平均的な地盤の有効熱伝導 率 $\bar{\lambda}_{\mathrm{s}}(\mathrm{W} /(\mathrm{m} \cdot \mathrm{K}))$ が求まる。

$$
\bar{\lambda}_{\mathrm{s}}=\frac{Q}{4 \pi \mathrm{L} k}
$$

ここで，Lは地中熱交換器の設置深度 $(\mathrm{m})$ である.また 熱交換器の熱抵抗 $R_{\mathrm{b}}((\mathrm{m} \cdot \mathrm{K}) / \mathrm{W})$ が，加熱を開始した初期 段階での温度挙動と地盤の初期温度との差及び熱特性を 用いて下式により求まる. 


$$
R_{\mathrm{b}}=\frac{L\left(t(\tau)-t_{0}\right)}{Q}-\frac{1}{4 \pi \bar{\lambda}_{\mathrm{s}}}\left[\ln \left(\frac{4 \bar{a}_{\mathrm{s}} \tau}{r_{\mathrm{b}}^{2}}\right)-\gamma\right]
$$

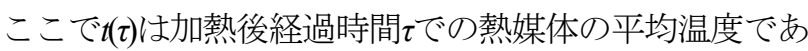
り, $\tau=1 \mathrm{hr}$ の場合, 式(1)の切片l一一致する. toは地盤の 初期温度 $\left({ }^{\circ} \mathrm{C}\right) ， \bar{a}_{\mathrm{s}}$ は温度伝導率 $\left(\mathrm{m}^{2} / \mathrm{hr}\right)$ で， $\bar{\lambda}_{\mathrm{s}}$ を $c_{\mathrm{s}}$ 及 び $\rho_{\mathrm{s}}$ で除した值，恔オイラー定数（=0.5772）である.

近年では, 線熱源理論での高次項に着目し逆解析法に より, 有効熱伝導率のみならず体積熱容量を含めて同定 する手法も提案されている20). また加熱中だけでなく, 加熱停止後の温度挙動に対しても, 線熱源理論を適用す ることも可能であり， $\tau$ と加熱停止後の経過時間 $\tau$ を用 いて $\bar{\lambda}_{\mathrm{s}}$ が下式で求めることができる.

$$
\begin{gathered}
t=k^{\prime} \ln \frac{\tau}{\tau-\tau^{\prime}}+l^{\prime} \\
\bar{\lambda}_{s}=\frac{Q}{4 \pi L k^{\prime}}
\end{gathered}
$$

ここで, $k$ は温度の回復（冷却）過程での温度の対数時 間に対する勾配 (K/n cycle)であり，l'は時間に依存しない 定数項 $\left({ }^{\circ} \mathrm{C}\right)$ である. 本手法は加熱時の熱媒体の温度挙 動を用いる加熱時法（従来法）に対し，「回復時法」と 呼ばれる. 回復時法は, 試験時間を余分に必要とするが, 加熱停止後の温度挙動は, 地中熱交換器の熱抵抗の影響 を受けず，有効熱伝導率を直接反映するため，深度毎の 有効熱伝導率の推定にしばしば用いられる

\section{b) 複層地盤の各層の有効熱伝導率の推定（提案法）}

本節では，線熱源理論に基づく解析的手法（式(1)〜 (3)）を，光ファイバー温度計による多点測定データを 用いて，図-1に示寸複層地盤の各層に適用する手法を示 す. 本来, 線熱源理論は無限線熱源を仮定するが，点熱 源の重㸚合わせで求まる有限線熱源の温度分布も一定層 厚以上あれば，熱応答試験が対象とする1〜2日程度の短 い時間範囲では周辺の温度挙動は一致する21).

各層に線熱源理論が成立できると仮定すると，従来法 と同様, $i$ 層 $(i=1,2, \cdots, N)$ の有効熱伝導率 $\lambda_{s i}(\mathrm{~W} /(\mathrm{m} \cdot \mathrm{K}))$ は, 式(3)に基づき下式により求まる.

$$
\lambda_{s i}=\frac{Q_{i}}{4 \pi L_{i} k_{i}}, i=1,2, \cdots, N
$$

ここで， $Q_{i}$ は $i$ 層の熱交換量 $(\mathrm{W}), k_{i}$ は $i$ 層を流孔る熱媒 体温度の対数時間 1 サイクルの変化勾配 $(\mathrm{K} / \mathrm{ln}$ cycle) である. $k_{i}$ は， $i$ 層中の光ファイバー温度計の各測定点での, 往 き還りの熱媒体温度の時間変化勾配 $k_{\mathrm{fj}}(\mathrm{z}), j=1,2, \quad \mathrm{z}_{\mathrm{o}}(\mathrm{i}-1) \leq$ $z \leq Z_{b i}$ 従来法と同様，加熱時間（例えば $\tau=12 \sim 60 \mathrm{hr}$ ) に対し, 最小二乗法で求め, 層内全体で平均して求める.

$$
k_{i}=\frac{1}{2 n_{z i}} \sum_{j j=1}^{n_{i j}} \sum_{j=1}^{2} k_{f j}\left(z_{b(i-1)}+(j j-1) d z\right)
$$

ここで, $n_{z i}$ は $i$ 層の光ファイバー温度計の測定点数であ
り, $n_{i}=\left(\mathrm{Z}_{\mathrm{b} i}-\mathrm{Z}_{\mathrm{b}(i-1))}\right) / d z+1=L_{i} / d z+1$ である. 解析対象層 は, 線熱源理論が適用できる一定以上の $L_{i}$ 必要である と考えられるが，その值は各層内の不均質性や試験条件 などに依存すると考えられる.このため, 本研究では, 解析する各層で $n_{z i}$ を徐々に増加させて計算し, その収束 性を確認寸ることで, 線熱源理論に基づく解析法の各層 への適用の妥当性を評価した.

$Q_{i}$ の計算は, 式(2)の $\Delta t \mathrm{t} の$ 代わりに, $i$ 層での熱媒体の 往き還りの深度方向の温度変化の和とする. 寸なわち,

$$
Q_{i}=c_{\mathrm{f}} \rho_{\mathrm{f}} v_{\mathrm{f}}\left(\Delta t_{\mathrm{f} 1}^{(i)}+\Delta t_{\mathrm{f} 2}^{(i)}\right) \cong c_{\mathrm{f}} \rho_{\mathrm{f}} v_{\mathrm{f}}\left(-m_{1}^{(i)}+m_{2}^{(i)}\right) L_{i}
$$

ここで, $\Delta t_{\mathrm{fl}}^{\left({ }^{(i)}\right.}, \Delta t_{\mathrm{t} 2}{ }^{(\mathfrak{)})}$ はi層での熱媒体の往き還りの深度方 向の温度変化 $(\mathrm{K})$ である. 測定温度の精度が十分高い場 合, $\Delta t_{t_{1}}^{(i)}, \Delta t_{t 2}^{(i)}$ は各層の上下端の温度差を計算すればよい が, 本研究では温度計の測定誤差を考慮し, 測定温度の 深度分布を線形式で近似し，その勾配から推定する。

$$
t_{\mathrm{fj}}(\mathrm{z}) \cong m_{j}^{(i)} z+b_{j}, z_{\mathrm{b}(i-1)} \leq z<z_{\mathrm{bi}}, j=1,2
$$

ここで， $m_{1}^{(i)}, m_{2}^{(i)}$ は各層での熱媒体温度の深度方向の勾 配 $(\mathrm{K} / \mathrm{m})$ である. 加熱した熱媒体温度が往き還りの過程

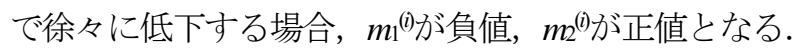
$m_{\mathrm{j}}^{(i)}$ は, ある観測時点 $\tau$ でのi層の温度分布 $\mathrm{t}_{\mathrm{j} j}$ 力ら, 解析す る加熱時間（例えば $\tau=12 \sim 60 \mathrm{hr}, 1 \mathrm{~min}$ 間隔の場合, 2880 時点）全てに対し最小二乗法で計算し, 平均する. 厳密 には，Uチューブ内の熱媒体温度の深度分布は線形では ないが22，近似的な線形を仮定することで，効率的に $m_{j}^{(1)}$ を計算する. なお各層の $Q_{i}$ の和は, Pt100温度計の往き 還り温度から, 式(2)で計算する $Q$ との一致を確認する.

$$
Q=\sum_{i}^{N} Q_{i}
$$

式(7)〜(10)を繰り返すことで，各層の $\lambda_{\mathrm{si}}$ が推定できる. これらと層厚 $L_{i}$ の重ね合せ平均は, 地中熱交換器全体の 有効熱伝導率に相当する ${ }^{13}$ ことから, 従来法の式(3)で求 まる $\bar{\lambda}_{\mathrm{s}}$ との一致を確認する.

$$
\bar{\lambda}_{\mathrm{s}}=\frac{1}{L} \sum_{i}^{N} \lambda_{s i} L_{i}
$$

なお各層の層厚の和は, 全体層厚に等しい $\left(L=\Sigma L_{i}\right)$.

\section{3. 光ファイバ一温度計の測定誤差と補正}

\section{（1）熱応答試験における測定温度の誤差}

光ファイバー温度計は, 熱媒体の循環を損なうことな $<$, 深度 $100 \mathrm{~m}$ の地中熱交換器内での多点測定が可能な 利点がある一方, 測定精度は従来用いるPt100温度計な どに比べ劣り, 測定誤差は $\pm 1 \mathrm{~K}$ 程度とされる(14). 本研 究で用いた測定機器は, 光ファイバーの両端から交互に 
光信号を発信することで距離减衰の影響を相殺するルー プ測定法を採用しているが，その場合も誤差は土 $0.5 \mathrm{~K}$ 程度である.これらの誤差は施設の温度監視など用途に よっては十分だが，熱応答試験での熱媒体の往き還りの 温度差は通常 $4 \mathrm{~K}$ 程度 8 に対し，相対誤差は $10 \sim$ 数 $10 \%$ 以 上となるため, 解析への影響が懸念される.

温度計の誤差は, 機器特有の系統誤差と，ランダムな 偶然誤差に分けられる.Pt100温度計など測定が安定す る温度計を使う場合，系統誤差のみに着目し，校正式で 補正する ${ }^{23}$. 一方, 光ファイバー温度計は各測定時での ゆらぎによる偶然誤差が大きい。ここで, 系統誤差と偶 然誤差を合成した標準誤差をそれらの算術和で表す24.

$$
e=\gamma_{\alpha} \frac{u}{\sqrt{n}}+\delta
$$

ここで，eは標準誤差 $(\mathrm{K}), u$ は偶然誤差（平均ゼロ）の 標準偏差 $(\mathrm{K}), n$ は観測点数, $\gamma_{\alpha}$ は標本数 (測定点数) $n$ に対する信頼区間 $\alpha$ （両側）でのスチューデントの分布

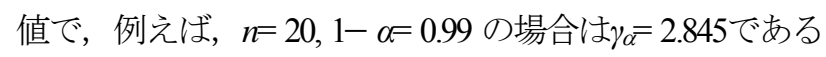
$\delta$ は系統誤差 $(\mathrm{K})$ であり，一定温度条件下において，十分 な観測点数による平均と真值との差とする.

式(13)よりnを多くすれば，第1項の偶然誤差が小さく なり，eは小さくなる．しかしながら熱态答試験では熱 媒体の温度が上昇し続けるため，平均区間を増やしnを 多くしすぎると，温度上昇が平滑化され，式(8)におけ る各測定点での温度上昇勾配 $k_{f j}$ の推定精度が低下寸る.

ここで，光ファイバー温度計の測定を毎分測定とする 場合, 平均区間の観測時間 $(\mathrm{min})$ と観測点数は一致し, これを $n_{\mathrm{t}}$ とする. 平均区間での加熱による変動量 $k \ln (60 \tau$ $\left.+n_{t}\right)-k \ln \tau$ の1/2を, 式(13)に加えた標準誤差を設定する.

$$
e=\gamma_{\alpha} \frac{u}{\sqrt{n_{\mathrm{t}}}}+\delta+\frac{k}{2} \ln \left(1+\frac{n_{\mathrm{t}}}{60 \tau}\right)
$$

式(14)において，kは試験毎で異なるが，わが国の一般的 な地盤) として, 式(3)に $q=40 \mathrm{~W} / \mathrm{m}, \lambda_{s}=1 \sim 3 \mathrm{~W} /(\mathrm{m} \cdot \mathrm{K})$ を代 入すると， $k=1 \sim 3 \mathrm{~K} / \mathrm{ln}$ cycleとなる. 式(14)より毎分測定 でntを大くすると，第1項の偶然誤差が小さくなるが, 第3項の加熱による温度上昇による変動が大きくなる.

測定誤差 $e$ を最小とする, 系統誤差の補正量 $(-\delta)$ 及び 平均処理区間 $n_{\mathrm{t}}$ は, 使用する機器の特性に依存するため, 室内実験などで設定することになる.

\section{（2）室内実験による測定誤差の評価と補正}

用いた光ファイバー温度計の測定誤差について，恒温 水槽を用いた室内実験により評価を行った. 2本の光つ アイバー温度計（ch1, ch2, 各延長 $100 \mathrm{~m}$ ）を恒温水槽に 浸し, 恒温水槽内の基準温度を 3 パターン $\left(t_{\mathrm{c}}=11.4\right.$, 28.2，45.1 ${ }^{\circ} \mathrm{C}$ ) に設定し，距離間隔 $0.5 \mathrm{~m}$ ，時間間隔 $1 \mathrm{~min}$ にて, 各パターン 1時間（計61点）での度測定を行った。 測定結果の統計值を, 表-1にまとめる. 表-1では, 各
点の測定值と基準水温 $t_{\mathrm{c}}$ の偏差の1時間平均を系統誤差 $\delta$, 偏差の標準偏差を偶然誤差の標準偏差 $u$ とした．また標 準偏差uの正規性の仮説検定結果 ( $p$ 值) も示し, 検定水 準 0.05 では測定誤差の正規性の仮定を否定しない結果を 得た. $\delta$ 'は以下に述べる校正式と平均処理 $(n=20)$ で 補正した後の偏差平均である. なお, 当然ながら温度計 は個々で温度特性が異なるため, 表-1の結果は今回の観 測機器のみに適用される.

表-1より, 本研究で用いた測定機器の系統誤差 $\delta$ は, 恒温槽の基準温度が $t_{c}=28.2^{\circ} \mathrm{C}$ 場合にほぼゼロとなり, それより切が低いと測定值は実際より高め，それよりtが 高いと実際より低めに計測される。このため, 系統誤差 の校正は, 単純才フセットによる校正ではなく, to の1次 校正式を用いることとし，その係数は，3パターンのtにに おけるch1, ch2での平均測定温度 $\delta$ から, 最小二乗法に より設定した $\left(\delta=-0.0282 t_{\mathrm{c}}+0.705\right)$.

一方，標準偏差は，ch1, ch2ともu=0.2〜0.4 Kであり， toを変えた場合もその差は比較的小さい. そこで平均化 する光ファイバー温度計の観測点数を $n_{\mathrm{t}}=5,10,20,30,60$ とした場合の，3パターンのtcに対するch1, ch2での標準誤 差eを，式(14)により計算し比較した（図-2）。なお計算 は, $\tau=12 \mathrm{hr}, k=2 \mathrm{~K} / \mathrm{ln}$ cycleの条件で行った. これより測 定温度を， $n=20$ (毎分測定で $20 \mathrm{~min}$ ）として平均処理す ることで，いずれのtでも， ch1 とch2の標準誤差は，e= $0.14 \sim 0.21 \mathrm{~K}$ 範囲で最小となる. なお $0.2 \mathrm{~K}$ の標準誤差 は, 熱媒体温度差 $4^{\circ} \mathrm{C}$ 場合の相対誤差 $5 \%$ に相当する. また各層の有効熱伝導率の推定時には, 式(8)及び式(10) により各層内の測定データを平均化するため, 測定誤差

\begin{tabular}{|c|c|c|c|c|c|c|c|c|}
\hline \multirow{2}{*}{$\begin{array}{c}t_{\mathrm{c}} \\
\left({ }^{\circ} \mathrm{C}\right)\end{array}$} & \multicolumn{2}{|c|}{$\delta(\mathrm{K})$} & \multicolumn{2}{|c|}{$u(\mathrm{~K})$} & \multicolumn{2}{|c|}{$P$} & \multicolumn{2}{|c|}{$\delta^{\prime}(\mathrm{K})$} \\
\hline & ch1 & $\operatorname{ch} 2$ & ch1 & $\operatorname{ch} 2$ & ch1 & $\operatorname{ch} 2$ & ch1 & $\operatorname{ch} 2$ \\
\hline 11.4 & 0.3 & 0.33 & 0.24 & 0.25 & 0.13 & 0.8 & -0.02 & 0.13 \\
\hline 28.2 & 0.02 & -0.03 & 0.25 & 0.3 & 0.24 & 0.13 & 0.12 & 0.06 \\
\hline 45.1 & -0.6 & -0.55 & 0.34 & 0.40 & 0.19 & 0.48 & -0.12 & 0.01 \\
\hline
\end{tabular}

表-1 2 本の光ファイバー温度計(ch1,ch2)の室内実験結果

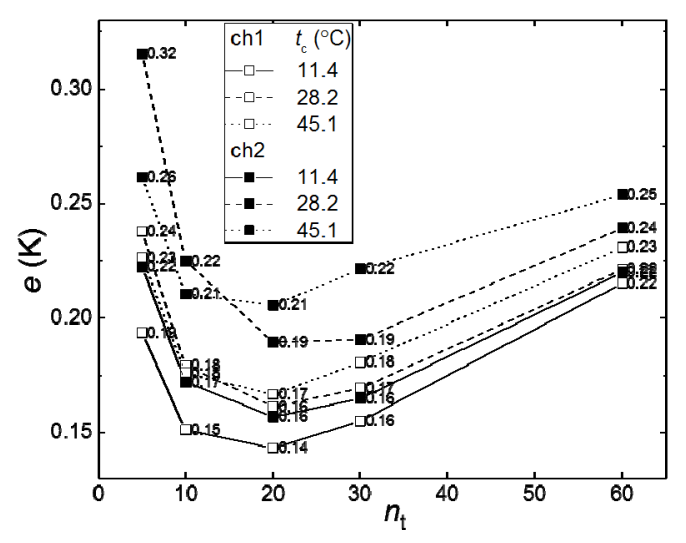

図-2 平均区間 $n_{\mathrm{t}}$ を変えた場合の標準誤差 $e$ の変化 
の影響は更に軽減される，以上から，本研究では，光フ アイバー温度計の測定值は上述の 1 次校正式と $n=20$ での 平均処理により補正した後に，解析に用いることとした

図-3に, ch1の光ファイバー温度計の測定值, 補正值 の基準水温に対寸る偏差Re $(\mathrm{K})$ を示寸，各基準温度で補 正前後（上下）を比べると，系統誤差の校正と偶然誤差 の平均化で測定誤差が軽減されているのが分かる. 補正 後の平均偏差は, $\delta{ }^{\prime}=-0.06 \sim 0.12 \mathrm{~K}$ (表-1）であり，期 待される誤差範囲（ $\pm 0.2 \mathrm{~K}$ 以内）に収まっている.

測定精度をより高めるには，まず恒温水槽の基淮温度 のパターンを増やし，系統誤差の校正式の精度を高める ことが挙げられる．また偶然誤差の平均時間を超えた長 周期の誤差あるいは，誤差自体の自己相関性の議論も必 要である，例えば，室内実験では，恒温槽の基準温度が 室温よりも $20 \mathrm{~K}$ 以上高い場合 $\left(t_{c}=45.1^{\circ} \mathrm{C}\right)$ ， ヒーターの 加熱周期の影響が現れている（図-3の右下図）。実際の 試験でも，昼夜の気温の変動や熱応答試験機に供給する 電源のゆらぎやノイズにより平均処理の時間区間を超え る長周期の誤差が発生する。 この場合, 偶然誤差は無相 関ではなくなり, 熱媒体の温度の時間勾配の推定に際し 単純な最小二乗法では最適解が得られないことになる.

このため, 次章の解析事例では, 系統誤差の校正と偶 然誤差の平均処理を行った補正データでの解析に加え, 様々なノイズから一定勾配の温度上昇（試験時間相当の 長周期信号）を取り出すための高速フーリエ変換(FFT) によるローパスフィルターによりスムージングしたデー タでの解析を行った．また誤差の自己相関の影響の可能
性に対し，補正データからランダム標本を作成し，それ ぞれで有效熱伝導率を計算し，その中央值を採用する， ブートストラップ法250の解析も行い, 結果を比較した.

\section{4. 地層別有効熱伝導率の解析事例}

\section{(1) 試験の概要}

光ファイバー温度計を用いた熱応答試験の解析事例と して，北海道上川支庁旭川市街地のGSHPs導入予定現場 (北緯 $43^{\circ}$ 48.1 $1^{\prime}$ 東経 $142^{\circ} 25.1^{\prime}$ ) での結果を紹介する。 旭川は，大雪山系を源とする石狩川と忠別川など大小支 川が合流する汇濫低地に位置し，地下には基盤となる堆 積岩や火山噴出物が分布し，それらを覆って砂，泥，䂿 などの汇濫堆積物が分布する. 試験箇所は石狩川の左岸 約 $1 \mathrm{~km}$ に位置し, 汇濫堆積物は粗粒な碩層が主体となる。 地中熱交換器の施工は，ボアホールを $\phi 179 \mathrm{~mm}$ で深 度101 mまで掘削した後，PE100シングルUチューブ (呼 び径32 A，OD: 40 mm, ID: $32 \mathrm{~mm}$ ）を挿入後，珪砂を充填 している．掘削時の記録より深度 $65 \mathrm{~m}$ 以深に新第三系の 泥岩が基盤，その上位に深度 $30 \mathrm{~m}$ まで更新統の礫混じり 粘性土〜粘性土が分布し，更にそれを覆って完新統の砂 确層が粘性土や砂を狭在しながら地表まで堆積する。こ のため, 地中熱交換器周辺の地層は大きく，第1層 $(\mathrm{Ag}$ : $\left.L_{1}=30 \mathrm{~m}, \mathrm{Z}_{1}=30 \mathrm{~m}\right)$, 第2 2 層 $\left(\mathrm{Dc}: L_{2}=35 \mathrm{~m}, \mathrm{Z}_{2}=65 \mathrm{~m}\right)$, 第3層 $\left(\mathrm{T}: L_{3}=36 \mathrm{~m}, z_{3}=101 \mathrm{~m}\right.$ )に分類することができる. 柱状図 及び地中熱交換器の模式図を, 図-4に示す.
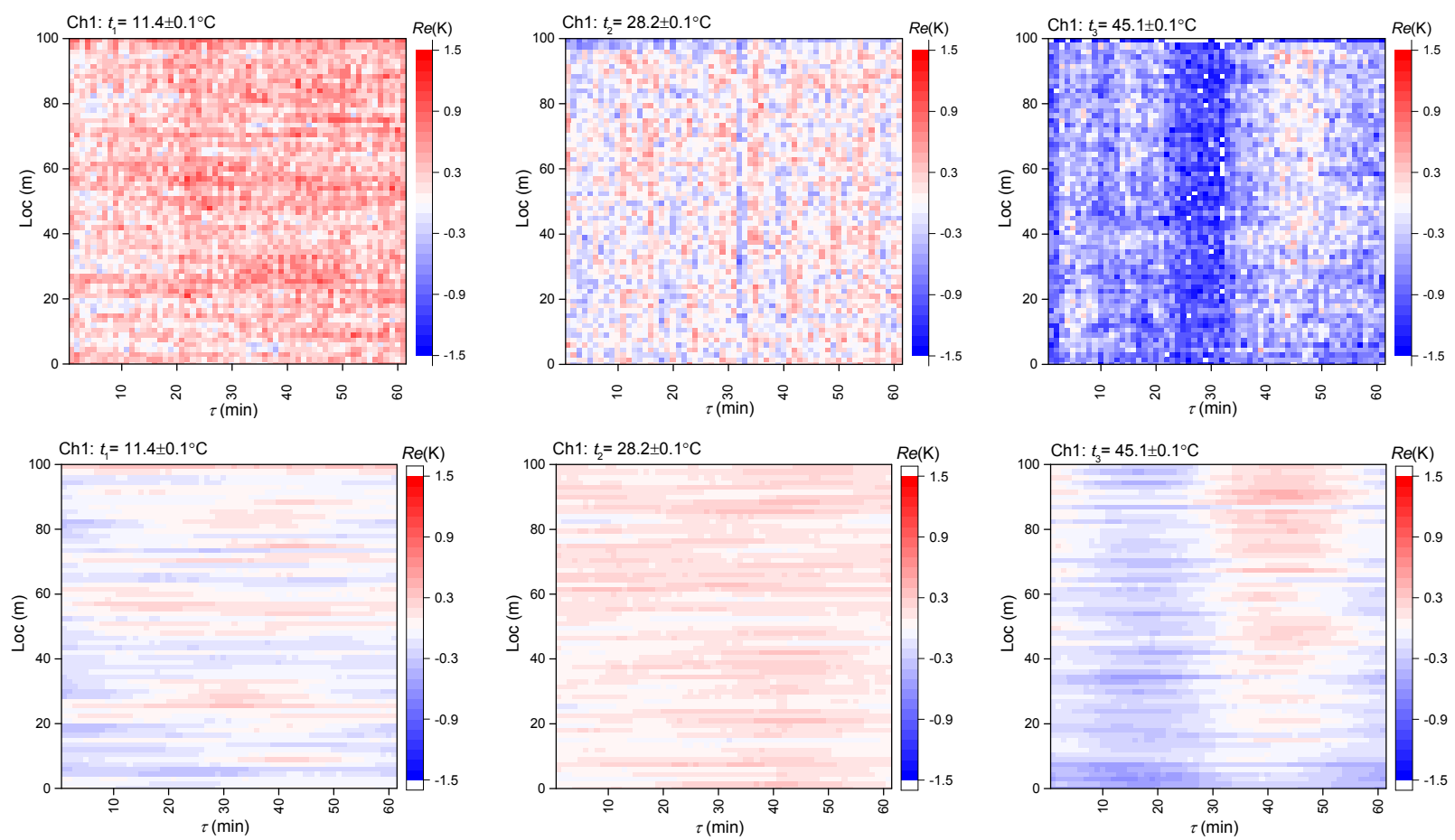

図-3 光ファイバー温度計(chl)の測定点（縦軸）・時間（横軸）毎の，測定温度一基準温度（上）及び補正温度一基準温度（下） 
熱応答試験は，2015年4月20日にPt100温度計を用いて 深度 $0.5 \mathrm{~m}$ 毎に初期地温を測定した後，熱応答試験機を設 置し，5月7日9時から5月9日17時まで計56時間に渡り， 熱媒体（エチレングリコール40\% \% w 水溶液）の循環流量 を $V_{\mathrm{f}}=15 \mathrm{~L} / \mathrm{min}$, 地表の往き還り温度差 $\Delta t=4.2 \mathrm{~K}$ 一定と して行われた．加熱停止後，5月10日21時まで回復時の 温度挙動の測定を行った. 光ファイバー温度計は, 往き 還りのUチューブそれぞれに測定間隔 $0.5 \mathrm{~m}$ で深度 $101 \mathrm{~m}$ まで設置し，試験中は毎分測定を行い，系統誤差の校正 及び偶然誤差に対する平均処理 $(n=20)$ を行った.

図-5は，Pt100温度計での地表での熱媒体の往き還り温 度測定による従来法の解析結果である. 加熱開始後から 終了まで（ $\tau=12 \sim 56 \mathrm{hr} ）$ まで，対数時間に対し熱媒体の 平均温度 $t_{\mathrm{f}}$ は良好な直線関係を示した（ $k=1.76 \mathrm{~K} / \mathrm{ln}$ cycle). その結果, $L=101 \mathrm{~m}$ に対し, 式(3)より $\bar{\lambda}_{\mathrm{s}}=1.77$ $\mathrm{W} /(\mathrm{m} \cdot \mathrm{K})$, 式(4)より $R_{b}=0.12(\mathrm{~m} \cdot \mathrm{K}) / \mathrm{W}$ 求められた.

\section{（2）地中熱交換器内の熱媒体の温度挙動}

図-6は，試験前及び試験中の熱交換器内での熱媒体の 温度プロファイルの抜粋である. 試験前に測定した温度 プロファイルによれば，地温は春先の気温の影響で地表

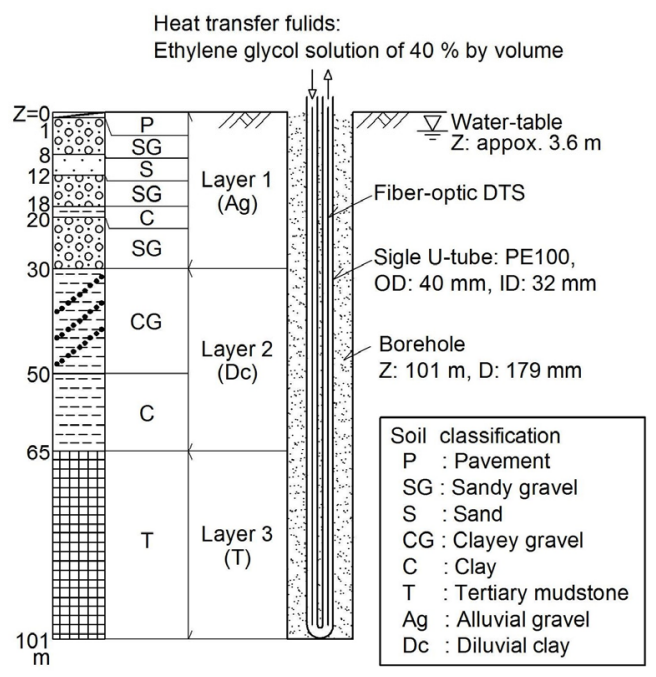

図-4 試験サイトの柱状図と地中熱交換器 模式解説図

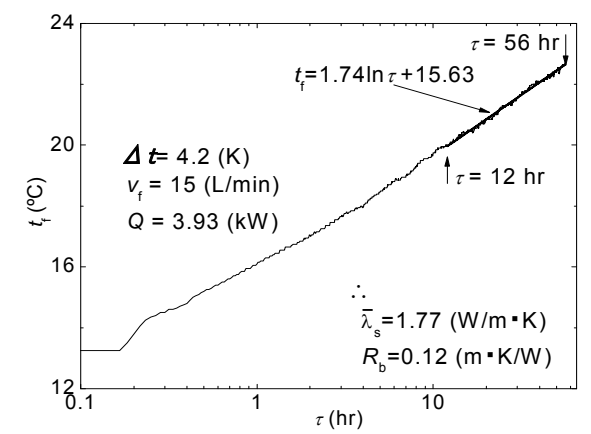

図-5 試験サイトでの熱応答試験解析結果（従来法）
付近が低く, 深度 $10 \mathrm{~m}$ 上で上昇した後, 再び梁度 $50 \mathrm{~m}$ 付 近まで低下を続け，深度 $50 \mathrm{~m}$ 以深では，約 $1 \mathrm{~K} / 100 \mathrm{~m}$ で緩 やかに上昇する. このため, 結果的に試験直前の地温分 布は全体に変化が小さかった。 なお試験直前の非加熱で 熱媒体を循環した時の平衡水温は $11.1^{\circ} \mathrm{C}$ であった.

試験中の地中熱交換器内の熱媒体の温度プロファイ ルは，往き還りで滑らかに温度が減少せず，細かいゆら ぎが認められる。これは，校正及び平均処理では未だ光 ファイバー温度計の測定䛊差を除去しきれなかったこと を示唆する．ただし大局的には，温度プロファイルは実 際の温度分布を反映すると考えられる，表-2に，地層毎 の熱媒体温度の深度勾配をまとめている．深度勾配は熱 媒体の温度分布が深度に対して線形とし, 最小二乗法に より求めた. 加熱後 $\tau=1 \mathrm{hr}$ で往きの温度分布が， $\tau=2 \mathrm{hr}$ で還りの温度分布が最大となり， $\tau=24 \mathrm{hr}$ 除き， 0.01 $\mathrm{K} / \mathrm{m}$ 程度の範囲で安定する. $\tau=24 \mathrm{hr}$ で一旦勾配が小さく なるのは, 光ファイバー温度計の長周期の測定ゆらぎ (誤差) と考えられる.このことから，式(10)での熱媒 体温度の深度勾配の計算は，単一の加熱時間だけで行わ ず，加熱時間の各測定時で行い，それらを平均した方が よいと言える.また往き還りの比較では, いずれの層も 往きの方が還りより深度勾配は大きい. これは，往きの

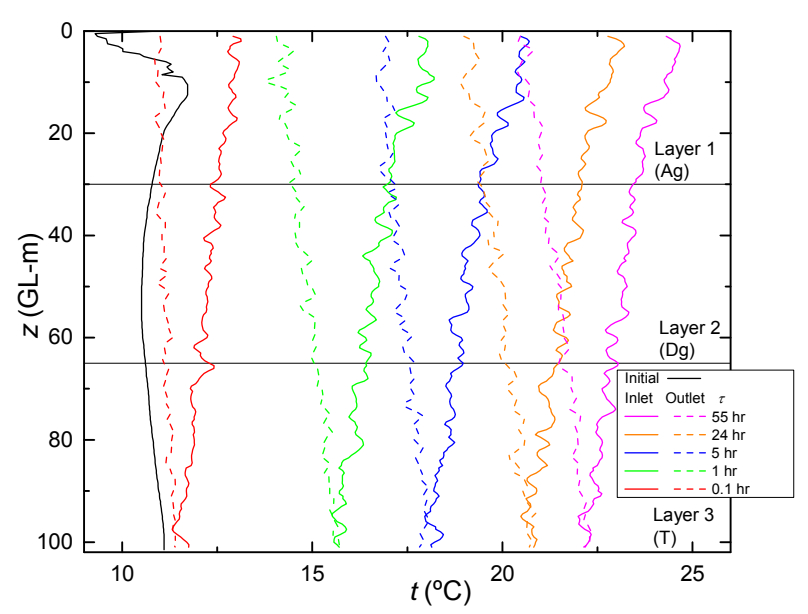

図-6 試験中の熱媒体温度の分布と時間変化（初期地温 2015 年 4 月 20 日測定， 2015 年 5 月 7 日 9時に加熱開 始)

表-2 地層毎の熱媒体温度の深度勾配（往き:上，還り:下） Inltet: $-m_{1}$

\begin{tabular}{|c|c|c|c|c|c|c|}
\hline$\tau(\mathrm{hr})$ & 0.1 & 1 & 2 & 5 & 24 & 55 \\
\hline Layer 1 & 0.019 & 0.041 & 0.045 & 0.044 & 0.039 & 0.042 \\
\hline 2 & 0.013 & 0.019 & 0.021 & 0.021 & 0.017 & 0.017 \\
\hline 3 & 0.018 & 0.021 & 0.021 & 0.019 & 0.019 & 0.020 \\
\hline & & & & & & $(\mathrm{K} / \mathrm{m})$ \\
\hline \multicolumn{7}{|l|}{ Outltet: $m_{2}$} \\
\hline$\tau(\mathrm{hr})$ & 0.1 & 1 & 2 & 5 & 24 & 55 \\
\hline Layer 1 & 0.000 & 0.002 & 0.015 & 0.016 & 0.003 & 0.014 \\
\hline 2 & -0.001 & 0.005 & 0.017 & 0.017 & 0.012 & 0.016 \\
\hline 3 & 0.012 & 0.007 & 0.014 & 0.016 & 0.012 & 0.015 \\
\hline
\end{tabular}


熱媒体がより周辺地盤との温度差が大きいためである.

\section{（3）層厚を変えた場合の有効熱伝導率の収束性}

各層の有効熱伝導率は，式(7)〜(10)を用いて推定する。 その際，各層の線熱源理論の適用性を示寸べく， $k_{i}$ の計 算(式(8))において， $n_{z i}$ を層中心のデータのみ用いた場合 $\left(n_{z i}=1\right)$ から, 層厚 $1 \mathrm{~m}$ 毎で層全体 $\left(n_{z i}=L_{i} / d z+1\right)$ まで増や し，それぞれの $\lambda_{s i}$ 計算した，その際， $Q_{i}$ は加熱開始 後 $\tau=12 \sim 56 \mathrm{hr}$ ，時間間隔を20 min $\left(n_{\mathrm{t}}=20\right)$ として平均処

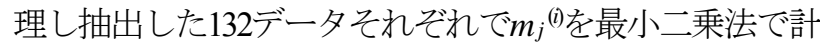
算した平均を用いた。計算結果を図-7に示す。

図-7によれば，いずれの層も $n_{z i}=41$ (層厚 $20 \mathrm{~m}$ ）付近 まで， $\lambda_{s i}$ の值は安定しない．特に $n_{z i}=21$ (層厚 $10 \mathrm{~m}$ ) 以 下では推定值のゆらぎが大きく，無限線熱源の仮定が成 り立たなくなるほか，層厚が小さいと平均化する測定点 が限られ，測定誤差が影響していると推測される．一方， $n_{z i}=21 \sim 41 （$ 層厚 $10 \sim 20 \mathrm{~m}$ ）になると， $\lambda_{\mathrm{s} i}$ の值は第2, 3層 ではおおむ㸚収束するが，第1層では依然ゆらぎが大き い. 第1層は主に砂碩で構成されるが，砂や粘性土が狭 在し，その不均質性が反映されたと推測する. $n_{\mathrm{z} i}=41$

（層厚 $20 \mathrm{~m}$ ）を超えると， $\lambda_{s i}$ の值は安定し，各層の推定 值として妥当と判断できる. 以降は，各層とも層内の全 測定点のデータ $\left(n_{z i}=L_{i} / d z+1\right)$ で解析した結果を示す.

\section{（4）異なるデータ処理による解析結果の比較}

図-8は，地表及び孔底での熱媒体温度の経時変化を示 している. 光ファイバーの測定值（左図）に見られる細 かいノイズは校正及び平均処理で軽減されている（中 図）。ただし，補正後もまだ細かいゆらぎが特に加熱時 に残るため, FFTローパスフィルター（周波数透過率 10\%以下）でスムージングを行うとより滑らかな温度変 化が得られる（右図）。なおスムージング後の両端は FFT特有の不連続が生じるため, 計算では除外している。

熱応答試験での観測誤差は，互いに自己相関性を有す る可能性があり，この場合，最小二乗法によるkiの推定 は最適解を得られない，このため，ランダムサンプリン グで作成した多数の観測標本で解析するブートストラッ プ法とも比較した. ここでは加熱後 $\tau=12 \sim 56 \mathrm{hr}$ での平 均抽出処理した 132 データより, エクセルrand関数によ りランダムに 50 点抽出した100 ケースを用意し，それぞ

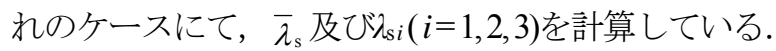

図-9に，ブートストラップ法による計算結果を示す. 100ケースの個々では解析結果が変わるものの, その変 化は10\%以内で安定している.このことより，本試験の 場合, 観測誤差に含まれる自己相関性の影響は小さく, 最小二乗法により十分な精度の推定が可能と判断する.

表-3に，解析結果をまとめる．上段が光ファイバー温 度計データから3層として解析した結果，下段がPt100温

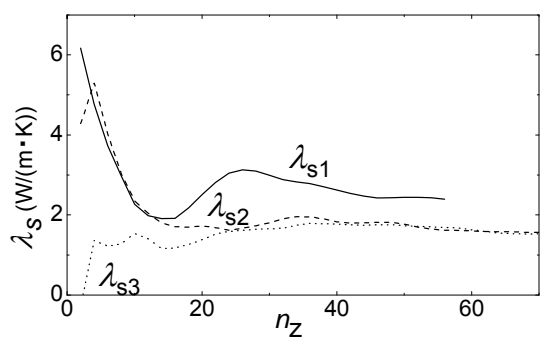

図-7 データ数 $n_{i}$ を变化させた場合の有効熱伝導率 $\lambda_{s i}$ の推移

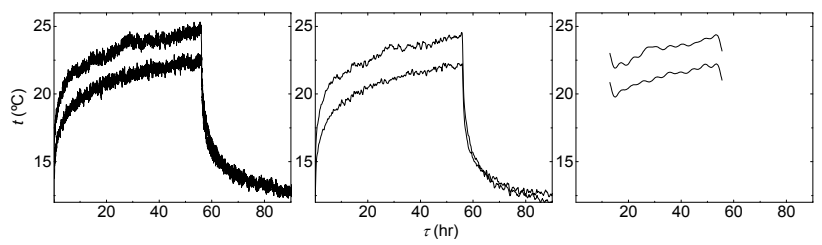

図-8 光ファイバー温度計による熱媒体の温度経時変化

（上線 : 往き深度 $Z=1 \mathrm{~m}$, 下線 : 往き深度 $Z=101 \mathrm{~m}$, 左 : 測定值, 中央 : 補正後, 右 : スムージング後)

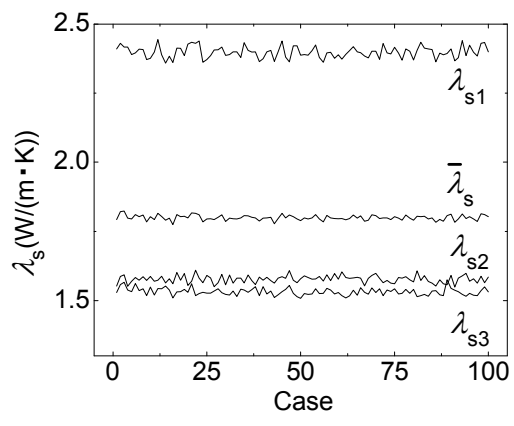

図-9 ブートストラップ法(100ケース)によ る有効熱伝導率の推移

表-3 試験サイトでの熱応答試験 解析結果

\begin{tabular}{|c|c|c|c|c|c|c|c|c|}
\hline \multirow{2}{*}{$\begin{array}{l}\text { Model } \\
\text { (Sensor) }\end{array}$} & \multirow{2}{*}{$\begin{array}{l}i \text { th } \\
\text { Layer }\end{array}$} & \multirow[t]{2}{*}{$L(\mathrm{~m})$} & \multirow{2}{*}{$\begin{array}{l}Q(\mathrm{~kW}) \\
\mathrm{H}\end{array}$} & \multirow{2}{*}{$\begin{array}{l}q(\mathrm{~W} / \mathrm{m}) \\
\mathrm{H}\end{array}$} & \multicolumn{4}{|c|}{$\lambda_{\mathrm{s}}(\mathrm{W} /(\mathrm{m} \cdot \mathrm{K}))$} \\
\hline & & & & & $\mathrm{H}$ & $\mathrm{F}$ & B & $\mathrm{R}$ \\
\hline Multi-layer & 1 & 30 & 1.52 & 50.8 & 2.39 & 2.36 & 2.40 & 2.48 \\
\hline (Fiber-optic & 2 & 35 & 1.22 & 35.0 & 1.56 & 1.54 & 1.58 & 1.53 \\
\hline \multirow[t]{2}{*}{ DTS) } & 3 & 36 & 1.20 & 33.3 & 1.52 & 1.49 & 1.53 & 3 1.42 \\
\hline & $1-3$ & 101 & 3.95 & 39.1 & 1.79 & 1.76 & 1.80 & 1.76 \\
\hline $\begin{array}{l}\text { Single-layer } \\
\text { (PT100) }\end{array}$ & $1-3$ & 101 & 3.93 & 38.9 & 1.77 & & & \\
\hline
\end{tabular}

$\mathrm{H}$ : 校正及び平均処理（加熱時）, F : H+FFT スムージング, $\mathrm{B}: \mathrm{H}+$ ブートストラップ法, $\mathrm{R}$ : 校正及び平均処理（回復時）

度計データから単一層として解析した結果である. $Q_{i}$ 及 び，それらを層厚で除した単位深度あたりの熱交換量 $q_{i}$ $(\mathrm{W} / \mathrm{m})$ は，校正及び平均処理による補正データ $(\mathrm{H})$ で計算 した值のみ示した。なお他データ処理でもほぼ同じ值が 得られている. $\bar{\lambda}_{\mathrm{s}}$ 及び $\lambda_{s i}(i=1,2,3)$ は，補正データを用 いた結果(H)に加え，FFTフィルターによるスムージング データを用いた結果(F), ブートストラップ法を用いた 結果(B)及び，回復時データを用いた結果 $(\mathrm{R}) を$ 比較した。 熱交換量の総和(式(11)） は $\Sigma Q_{i}=3.95 \mathrm{~kW}$ であり，Pt100 温度計の測定データから式(2)で計算される值 $Q=3.93$ 
$\mathrm{kW}$ とほぼ一致し，熱収支の整合を確認できる．また単 位深度当りの熱交換量は，第 1 層で $q_{1}=50.8 \mathrm{~W} / \mathrm{m}$ で，第2 層の值 $\left(q_{2}=35.0 \mathrm{~W} / \mathrm{m}\right)$ や第3 層の值 $\left(q_{3}=33.3 \mathrm{~W} / \mathrm{m}\right)$ に比べ, 約1.5倍高い值となった. 有効熱伝導率も，式(12)による 層厚重ね合わせ平均した值 (Layer 1-3)は, データ処理を 変えても $1.76 \sim 1.80 \mathrm{~W} /(\mathrm{m} \cdot \mathrm{K})$ の範囲にあり, 従来法による 推定值 $\bar{\lambda}_{\mathrm{s}}=1.77 \mathrm{~W} /(\mathrm{m} \cdot \mathrm{K})$ と相対誤差 $2 \%$ 範囲でほぼ一致 する. また各層の有効熱伝導率は，いずれのデータ処理 でも中央值（補正データでの結果 $(\mathrm{H})$ ）に対し， $\pm 5 \%$ の 範囲で互いに一致する. 以上より, 光ファイバー温度計 の校正及び平均処理を行うとともに，一定層厚以上 $(20$ $\mathrm{m}$ 以上）で解析を行えば，その後のデータ処理によらず， 安定した解析結果が得られることが示された.

\section{(5) 結果の考察}

本研究では, 旭川市の複層地盤において, 2本の 光ファイバーを用いた熱応答試験を実施し, 多点測 定を活かした線熱源理論による解析的手法を各層に 適用することで, 地層別の有効熱伝導率を推定した。

試験箇所の地盤を構成する3層の有効熱伝導率の 層厚重み付け平均は, Pt100温度計による従来法で の值と相対誤差 $2 \%$ の範囲に収まる.また光ファイ バー温度計の測定データに対し, 校正及び平均処理 の補正のみならず，スムージングやブートストラップ 法, 回復時法など, デー夕処理を変えて解析しても安定 した結果が得られた．したがって，2本の光ファイバー 温度計を用いて，熱媒体の往き還り温度のUチューブ 内の深度分布とその挙動を測定し, 提案するデータ の補正と線熱源理論に基づく解析を行うことで，一 定層厚以上（層厚 $20 \mathrm{~m}$ 以上）の地層の有効熱伝導率 を，従来法と同精度で推定可能であると判断できる。 各層の有効熱伝導率の推定値は, 最上位の砂碩層で $\lambda_{\mathrm{s}}=2.4 \mathrm{~W} /(\mathrm{m} \cdot \mathrm{K})$ であり, 中間層（粘性土層）の值（ $\lambda_{\mathrm{s} 2}=$ $1.5 \mathrm{~W} /(\mathrm{m} \cdot \mathrm{K}))$ ）最下層（泥岩）の值 $\left(\lambda_{33}=1.5 \mathrm{~W} /(\mathrm{m} \cdot \mathrm{K})\right)$ に比べ, 約 1.5 倍高かった。 また砂碩層の一般值 $(2.0$ $\mathrm{W} /(\mathrm{m} \cdot \mathrm{K}))^{4)}$ と比べても20\%高い值である.この要因として, 試験箇所が石狩川近傍に位置することから，特に表層を 流れる地下水流れ (伏流水) による移流効果が推測され る. 第1層の単位深度当りの熱交換量は, $q_{1}=50.8 \mathrm{~W} / \mathrm{m}$ と 他層の約1.5倍であり, 同層に地中熱交換器を集中させ れば, 必要な採放熱量に対し掘削総延長を減らすことが できる可能性がある. 実際は, 掘削本数の増加によるコ ストや土地の制約などを考慮する必要があるが，各層の 有効熱伝導率の違いが明らかとなれば，その分布に応じ た適正な地中熱交換器規模の検討が可能となる.

最後に, 本研究での今後の課題を述べる. 光ファイ バー温度計は，Pt100温度計などと比べて未だ高価であ り, 本手法について様々な試験・地質条件で適用し，有
効性や適用限界を更に詳細に評価していく必要がある. 特に線熱源理論が適用できる試験条件は, 数值解析を含 めた議論が必要であり，今後の課題としたい。また実務 者向けのマニュアルや解析ツールの提供も本手法の理解 や普及に必要と考える. こうした課題が残るものの, 提 案する光ファイバー温度計を組み合わせた熱心答試験は, 従来法の試験・解析の延長で地層毎の有効熱伝導率の推 定を可能とし, 研究のみならず実務での利用を通じて, 地中熱利用の普及・促進に貢献することが期待される.

\section{5. まとめ}

本研究では，間接型地中熱交換器の熱応答試験におい て，2本の光ファイバー温度計を往き還りのUチューブ に設置し，熱媒体の温度挙動を測定することで，地層別 の有効熱伝導率の分布を推定する手法を示した.

以下に研究成果をまとめる.

1) 先行研究が1組の光ファイバー温度計を用いるのに対 し，2本の光ファイバー温度計を用いることで，地中 熱交換器内の熱媒体の温度挙動を往き還りともに把握 することで，地層毎の熱交換量をより正確に推定する ことが可能となる.

2) 提案する解析法は, 従来法と同じ線熱源理論に基づく 解析的手法を各層に適用する. 解析に用いる熱媒体の 時間変化勾配は, 光ファイバー温度計の各測定点で計 算し，それらの層内平均とし，熱交換量は往き還りそ れぞれの熱媒体温度の深度勾配を線形近似して, 熱容 量と層厚を乗じた和として推定した，

3) 光ファイバー温度計の測定值は, 系統誤差の校正及び 偶然誤差の平均処理による補正を行った. 本研究では, 恒温水槽での室内実験から, 系統誤差の1次校正式を 設定するとともに, 平均処理の時間区間を $20 \mathrm{~min} と し$ た結果，想定する標準誤差は $\pm 0.2 \mathrm{~K}$ 以内になった.

4) 北海道旭川市での解析事例では, 第1層（砂礫層）, 第2層（粘性土層），第3層（泥岩）の有効熱伝導率は, 層厚 $20 \mathrm{~m}$ 以上の区間で解析することで，いずれも安定 した值に収束した.3層の值の層厚重み付け平均や地 盤との熱交換量の和は，従来法で推定した有効熱伝導 率や熱交換量の值と, ほぼ一致する結果が得られた。

5) 解析に用いるデータを, 加熱時の校正と平均処理した 補正データのほか, FFTローパスフィルターによるス ムージングデータ，多数標本を生成したブートストラ ップデータ, 回復時データと変えた場合も, 有効熱伝 導率の推定值は，互いにほぼ一致した結果が得られた。 6) 試験箇所で推定された有効熱伝導率は，最上位の砂碟 層の值が他2層よりも約1.5倍高い結果となった．試験 箇所近傍を流れる石狩川に繫がる砂碩層中の地下水の 
移流効果を反映した可能性があり，同層に集中的に地 中熱交換器を配置することで，熱交換器全体の掘削延 長を減らせる見込みとなった。このように，本手法に より地層毎の有効熱伝導率を把握することで，地中熱 交換器の配置や掘削延長などの適正な規模の検討が可 能になる.

謝辞 : 本研究に際し，株式会社アリガプランニングには 試験サイトの提供並びに試験実施に際し，多大なご支援 を頂いた．試験実施に際しては，当研究室の中村真人氏 および橋本隼樹君の協力を得た．3名の匿名の查読者か らの有益なご意見により，本論文の改善がなされた．本 研究は，NEDO再生可能エネルギー熱利用技術開発事業 (研究代表者 : 長野克則) の一環として進められた。 こ こに記して謝辞とします。

\section{参考文献}

1）経済産業省・資源エネルギー庁：エネルギー基本計 画, http://www.meti.go.jp/press/2014/04/20140411001/, pp. 1-78, 2014.

2) 長野克則：地下熱利用技術 2. 地下熱利用技術とは, 地下水学会誌, Vol. 53, No. 1, pp. 83-90, 2011.

3) Spitler, J. D.: Ground-source heat pump system researchpast, present and future, International Journal of HVAC \& R Research, Vol. 11, pp. 165-167, 2005.

4) 北海道大学地中熱利用システム工学講座 : 地中熱七 ートポンプシステム, pp. 92-99, オーム社, 2007.

5) 葛隆生, 長野克則, 中村靖: 複層地盤を考慮した地 中熱交換器のシミュレーションツールの開発とその 応用, 日本冷凍空調学会論文集, Vol. 32, No. 3, pp. 335-344, 2015.

6) Mogensen, P.: Fluid to duct wall heat transfer in duct system heat storages, Proc. Int. Conf. on Subsurface Heat Storage in Theory and Practice, Stockholm, Sweden, pp. 652-657, 1983.

7) Gehlin, S.: Thermal response test-method development and evaluation, Ph.D. Dissertation, Luleå University of Technology, 2002.

8) 長野克則：ボアホール型地中熱交換器に対する加熱 法による熱応答試験の標準試験方法 ver. 2.0, ヒートポ ンプ・蓄熱センター, pp. 1-13, 2011.

9) 藤井光, 駒庭義人：地下熱利用技術 7. サーマルレス ポンス試験の原理, 地下水学会誌, pp. 391-400, 2011.

10）環境省水・大気環境局：地中熱利用にあたってのガ イドライン改訂版, http://www.env.go.jp/press/files/jp/ 26796.pdf, pp. 28, 2015.

11）国土交通省大臣官房：官庁施設における地中熱利用 システム導入ガイドライン（案）, www.mlit.go.jp/ common/001016159.pdf, pp. 12-21, 2013.

12) Ingersoll, L. R., Plass, H. J.: Theory of the ground pipe heat source for the heat pump, ASHVE Trans., Vol. 54, pp. 167-188, 1948.

13) Banks, D.: An Introduction to Thermogeology: Ground Source Heating and Cooling, $2^{\text {nd }}$ Edition, pp. 285-286, 410-431, Wiley-Blackwell, 2008.

14) Grattan, K. T. V. and Sun, T.: Fiber optic sensor technology: an overview, Sensors and Actuators, Vol. 82, pp. 40-61, 2000.

15) Günzel, U. and Wilhelm, H.: Estimation of the in-situ thermal resistance of a borehole using the distributed temperature sensing (DTS) technique and the temperature recovery method (TRM), Geothermics, Vol. 29, pp. 689-700, 2000.

16) 藤井光, 大久保博晃, 系井龍一, 小助川洋幸 : 不均 質地層に抢ける同軸型熱交換井の温度挙動解析, 日 本地熱学会誌, Vol. 27, No. 3, pp. 223-232, 2005.

17) 藤井光, 大久保博晃, 系井龍一, 小助川洋幸: 不均 質地層における U 字管型地中熱交換井の温度挙動解 析, 日本地熱学会誌, Vol. 28, No. 2, pp. 199-210, 2006.

18) Freifeld, B. M., Onstott, T. C., Toole, T. and Pratt, L. M.: Ground surface temperature reconstructions: Using in situ estimates for thermal conductivity acquired with a fiberoptic distributed thermal perturbation, Geophysical Research Letters, Vol. 35, L14309, 2008

19) Fujii, H., Okubo, H., Nishia, K., Itoi, R., Ohyama, K. and Shibata, K.: An improved thermal response test for U-tube ground heat exchanger based on optical fiber thermometers, Geothermics, Vol. 38, pp. 399-496, 2009.

20) 上原健人, 藤縄克之 : ケルビンの線源関数の高精度 漸近解とパウエルの共役傾斜法を用いた熱応答試験 関連パラメータの逆解析法とその適用, 地下水学会 誌, Vol. 55, No. 3, pp. 253-268, 2013.

21）永坂茂之, 横山真太郎, 落藤登, 中村真人, 長野克 則, 濱田靖弘：線源理論を用いた垂直埋設管の平均 表面温度の推定，空気調和・衛生工学論文集，No. 59, pp. 143-151, 1998.

22) Zeng, H., Diao, N. and Fang, Z.: Heat transfer analysis of boreholes in vertical ground heat exchangers, International Journal of Heat and Mass Transfer, Vol. 46, No. 23, pp. 4467-4481, 2003.

23) 岡田益己 : 温度の正しい測り方（2）温度計の校正, 生物と気象, Vol. 10, A-3, 2010.

24）吉澤康和：新しい誤差論, pp. 104-146, 共立出版, 1989.

25) Witte, H. J. L, van Gelder, G. J. and Spliter, J. D.: In situ measurement of ground thermal conductivity: the Dutch perspective, ASHRAE Trans: Research, Vol. 108, pp. 263273, 2002.

(2015. 11.6 受付) 


\title{
ESTIMATION OF EFFECTIVE THERMAL CONDUCTIVITIES \\ ACCORDING TO MULTI-LAYERS BY THERMAL RESPONSE TEST WITH A SET OF FIBER OPTICS IN A U-TUBE
}

\author{
Yoshitaka SAKATA, Takao KATSURA, Jian ZHAI and Katsunori NAGANO
}

This study improves thermal response test (TRT) by using a set of fiber-optic distributed temperature sensors (DTSs) to estimate effective thermal conductivities in multi-layered formations. These sensors are installed into both inlet and outlet pipes (a U-tube) to obtain vertical profiles of heat transfer fluid temperature at TRT in more detail than those obtained by single DTS as in previous studies. When the borehole is constructed in a formation with several horizontally layers, this study analyzes the effective thermal conductivity in each layer under the assumption of line heat source. In the analysis, the slopes of fluid temperature on logarithmic elapse time are averaged within each layer, and heat exchange rate is calculated using a sum of linear slopes of temperature with depth in both inlet and outlet pipes. Offset and averaging span for DTS calibration are evaluated by laboratory sink tests at constant temperatures. Finally, an example of the proposed method at Asahikawa City, Hokkaido, Japan, is shown. In the example, the formation consists of three layers; unconsolidated gravel, clay, and pre-Quaternary shale. The solutions of the effective thermal conductivity in each layer are converged commonly when the thicknesses for analysis are larger than 20 meters. The conductivity in the upper-gravelly layer is about 1.5 times larger than those in the mid-clayey and lower-shale layers, probably due to groundwater flow advection. The thickness-weighted average of conductivities in the three layers is almost equal to the conductivity by conventional TRT with Pt100 sensors. The solutions are also valid in terms of total heat exchange rate. In addition, a series of effective thermal conductivities is invariable among the cases of DTS data: 1) calibrated in the heating period, 2) smoothed additionally by the FFT low-pass filter, 3) randomly sampled as the boot-strap method, and 4) calibrated in the recovery period. 